\title{
Nutritional and quality changes in piglet concentrate affected by formulation and storage
}

\author{
[Mudanças nutricionais e de qualidade no concentrado de leitões afetadas pela formulação \\ e pelo armazenamento]
}

\author{
A. Cella1 (D) J.V. Ludke $e^{(\mathbb{D}}$, A. Coldebella ${ }^{(\mathbb{D})}$, M.C.M.M. Ludke ${ }^{3}$ (D) H.A. Siqueira ${ }^{(\mathbb{D})}$, \\ J.M. Oliveira $\mathrm{Jr}^{4}$ (D) V. Peripolli ${ }^{1,4^{*}}$, I. Bianchi ${ }^{1,4}$ (D) \\ ${ }^{1}$ Graduate, Instituto Federal Catarinense, Campus Araquari, Araquari, SC, Brasil \\ ${ }^{2}$ Embrapa Suínos e Aves, Concórdia, SC, Brasil \\ ${ }^{3}$ Universidade Federal Rural de Pernambuco, Recife, PE, Brasil \\ ${ }^{4}$ Instituto Federal Catarinense, Campus Araquari, Araquari, SC, Brasil
}

\begin{abstract}
The aim of this study was to evaluate the variations in the stability and nutrient concentration in concentrates for piglet feeding. Five treatments were established: T1 - Control, standard concentrate formulation (SCF); T2 - PXMore5, SCF with more 5\% vitamin-mineral premix (VMP); T3 - PXLess5, SCF with less 5\% VMP. All these three treatments used $400 \mathrm{~kg}$ batches in an INTECNIAL mixer; T4 - FeedMixer, SCF using a $4,000 \mathrm{~kg}$ batch in an IMOTO mixer; T5 - PremixMixer, SCF using a 1,200kg batch in an MUYANG mixer. For each treatment, bags of $20 \mathrm{~kg}$ were stored in three storage places for four months where room temperature and relative humidity was recorded daily. The concentration of nutrients was evaluated through centesimal and mineral analysis. The water activity of concentrate was affected by temperature and relative air humidity in different storage places. The greatest variation in concentration of crude protein, mineral residue, copper, zinc, and selenium was due to the PremixMixer treatment. Regarding the guaranteed levels, the critical value was verified only for the chrome concentration.
\end{abstract}

Keywords: acidity index, evolution of lipid compounds, microbiological analysis, shelf life, water activity

\section{RESUMO}

O objetivo deste estudo foi avaliar as variações na estabilidade e na concentração de nutrientes em concentrados para alimentação de leitões. Foram estabelecidos cinco tratamentos: T1 - controle, concentrado com formulação padrão (CFP); T2 - PXMais5, CFP com 5\% a mais de vitaminas e minerais da pré-mistura (PVM); T3 - PXMenos5, CFP com 5\% a menos de PVM (todos os três tratamentos utilizaram lotes de $400 \mathrm{~kg}$ em um misturador INTECNIAL); T4 - FeedMixer, CFP usando um lote de $4.000 \mathrm{~kg}$ em um misturador IMOTO; T5 - PremixMixer, CFP usando um lote de $1.200 \mathrm{~kg}$ em um misturador MUYANG. Para cada tratamento, sacos de $20 \mathrm{~kg}$ foram armazenados em três ambientes distintos por quatro meses, onde a temperatura ambiente e a umidade relativa do ar foram registradas diariamente. A concentração de nutrientes foi avaliada por meio de análises centesimal e mineral. A atividade de água do concentrado foi afetada pela temperatura e a umidade relativa do ar nos diferentes locais de armazenamento. A maior variação na concentração de proteína bruta, resíduo mineral, cobre, zinco $e$ selênio foi devido ao tratamento "MistPremix". Em relação aos níveis de garantia, foi verificado valor crítico apenas para a concentração de cromo.

Palavras-chave: análises microbiológicas, atividade de água, evolução dos compostos lipídicos, índice de acidez, tempo de prateleira

*Corresponding author: vanessa.peripolli@ hotmail.com

Submitted: April 7, 2021. Accepted: June 19, 2021 


\section{INTRODUCTION}

Feeding corresponds to 79 to $84 \%$ of the piglet production costs (Frigo and Miele, 2014) because in post-weaning diets it is necessary to include high quality and digestible ingredients to ensure maximum performance of the animals (Coneglian et al., 2011). In these complex diets, more than six dozen components are used, such as ingredient sources with specific nutrients, specific sources of essential nutrients, and technological additives such as flavorings, enzymes to increase digestibility, and adjuvant products to control the stability of the ration. The feed industries produce and trade specific concentrates to allow the wide use of the technologies available in piglet nutrition.

A key aspect for maintaining the quality of these concentrates is their stability, maintaining their physical and nutritional integrity from the moment they are prepared, stored, and used in the rations. The ingredients used to integrate the concentrates homogenously interact with each other during the storage period, and they are influenced by the relative air humidity and the temperature to which they are subjected (Longo et al., 2010). In addition to the physical stability of the ingredients and the mixture, the relevant factors for the nutritional quality of the concentrates and rations are the control of microorganism development (Longo et al., 2010), lipid oxidation (Gabbi et al., 2011), and mixing uniformity (Mccoy et al., 1994).

According to Cabarkapa et al. (2009), the microorganisms found in the ingredients and feed can be saprophytic, pathogenic, conditionally pathogenic, and toxic. Their growth and proliferation are dependent on many factors such as humidity, temperature, substrate, aerobic or anaerobic conditions, physicochemical properties of the ingredients, $\mathrm{pH}$ of the substrate, presence of technological additives and duration and storage conditions as well as the kind of products formed during the decomposition.

Lipid oxidation is an important technical problem in feed industries, and it is translated into rancidity, comprising sensory changes with the development of unpleasant odors and nutritional changes in rations and concentrates (Kerr et al., 2015; Shurson et al., 2015). The conditions for lipid oxidation to occur are the chemical structure with unsaturated fatty acids, presence of oxygen, exposure to light, high temperatures, presence of pro-oxidants (metals), and water activity (Goddard et al., 2012). Weaned piglets that received diets containing oxidized oil decreased the growth performance, nutrient digestibility, reduced antioxidant enzyme activity and increased the concentration of intermediate metabolites of lipid oxidation in plasma and liver (Yuan et al., 2007).

Developing diets for pigs demands attention to several particularities, making it a challenge, as many ingredients interact with each other and with the environment during their shelf life. Each formula is also influenced by the ingredients of its composition, storage conditions, relative humidity, and temperature to which they are subjected.

Therefore, the aim of this study was to evaluate the variations in the stability and nutrient concentration in concentrates for piglet feeding, according to the variations in the formulation, processing, and storage.

\section{MATERIAL AND METHODS}

This study was carried out in the South region, Brazil, in the period from December to April. The treatments were prepared in a feed industry located in the Western region of Santa Catarina state. The product evaluated was a concentrate recommended for piglets in the pre-initial phase used in the proportion of $400 \mathrm{~kg}$ per ton of ration, with a shelf life of 90 days.

Five treatments were established to evaluate quality variations, under monitored conditions, for up to 120 days of storage in three different geographical locations. The treatments were: T1 Control: Standard concentrate formulation (Table 2), using a $400 \mathrm{~kg}$ batch in an INTECNIAL mixer (model MH-400, Brazil); T2 - PXMore5: 400kg batch of concentrate (Table 2) in an INTECNIAL mixer (model MH-400, Brazil), using 5\% more mineral-vitamin premix for piglets (Table 1). The concentrate mixing procedure (Table 2) was identical to T1; T3 - PXLess5: 400kg batch of concentrate (Table 2) in an INTECNIAL mixer (model MH-400, Brazil), using 5\% less mineralvitamin premix for piglets (Table 1). The concentrate mixing procedure (Table 2) was identical to T1; T4 - FeedMixer: The concentrate 
formulation (Table 2) was identical to $\mathrm{T} 1$, however, in a batch of $4.000 \mathrm{~kg}$ in an IMOTO mixer (model MH-5000, Brazil); T5 PremixMixer: The concentrate formulation (Table 2) was identical to T1, however, with a $1.200 \mathrm{~kg}$ batch in a MUYANG mixer (model SJHS8, China).

The supplements added to the treatments (Table 1) were elaborated using the horizontal mixer MUYANG in batches of $1,800 \mathrm{~kg}$.

The chemical composition of concentrate and the nutritional concentration of treatments was presented in Table 2 .

The supplements and concentrates were prepared on the same day. The bagging of concentrates from each treatment was carried out in valved bags with properties to ensure the filling, conservation, and protection requirements following the MAPA standard (Brasil, 2009, 2015), specifying rules for packaging and labeling. After the production and packaging of the concentrates, the bags were transported to three marketing warehouses: Chapecó-SC, Araquari-SC, and São Gabriel do Oeste-MS (SGO). In each storage place, the bags were stored on pallets in an airy environment, protected from light and heat sources. The storage conditions for 120 days in the three locations were monitored using a thermohydrometer (AKSO, AK28 model, São Paulo, Brazil) that recorded the temperature and air relative humidity three times a day.

Table 1. Supplement composition $(\mathrm{g} / \mathrm{kg})$ used in the concentrate production

\begin{tabular}{lccc}
\multicolumn{1}{c}{ Ingredients (g/kg as is) } & $\mathrm{T} 1, \mathrm{~T} 4$ and T5 & $\mathrm{T} 2$ & $\mathrm{~T} 3$ \\
\hline Vitamin + mineral premix for piglets* & 66.6667 & 70.0000 & 63.3333 \\
Granulated dicalcium phosphate & 181.4444 & 180.7964 & 182.0925 \\
Calcitic limestone & 152.4444 & 151.9000 & 152.9889 \\
Granulated iodized salt & 33.7778 & 33.6571 & 33.8984 \\
Zinc Oxide 80\% & 74.0722 & 73.8077 & 74.3368 \\
Ground soybean meal & 73.6558 & 73.3924 & 73.9184 \\
L-Lysine HCl 99\% & 123.5333 & 123.0921 & 123.9745 \\
DL- Methionine 99\% & 56.2444 & 56.0436 & 56.4453 \\
L-Threonine 98,50\% & 46.0444 & 45.8800 & 46.2089 \\
L-Tryptophan 99\% & 10.8222 & 10.7836 & 10.8609 \\
Benzoic acid (E210) & 66.6667 & 66.4286 & 66.9048 \\
Anti-caking agent (E551**) & 26.6667 & 26.5714 & 26.7619 \\
Antioxidant (E310, E321, E330) & 13.3333 & 13.2857 & 13.3810 \\
Flavoring agent (Coconut + Vanilla) & 12.2222 & 12.1786 & 12.2659 \\
Sweeteners (E952, E954, E959) & 6.6667 & 6.6429 & 6.6905 \\
Zinc amino acid complex 16\% & 5.5556 & 5.5357 & 5.5754 \\
Iron amino acid complex 22\% & 3.0278 & 3.0170 & 3.0386 \\
Selenium yeast complex & 22.2222 & 22.1429 & 22.3016 \\
Organic chromium 3.4\% & 4.4444 & 4.4286 & 4.4603 \\
Choline chloride 60\% & 14.9333 & 14.8800 & 14.9867 \\
Protease enzyme / Phytase enzyme & 1.1111 & 1.1071 & 1.1151 \\
Beta-glucanase and xylanase enzyme & $4.4444 / 0.4444$ & $4.4286 / 0.4429$ & $4.4603 / 0.4460$ \\
\hline
\end{tabular}

* Vitamin $\mathrm{A} / \mathrm{D}_{3}$, vitamin $\mathrm{A}$, vitamin $\mathrm{E}$, menadione sodium bisulfite, vitamin $\mathrm{B}_{1}$, vitamin $\mathrm{B}_{2}$, vitamin $\mathrm{B}_{6}$, vitamin $\mathrm{B}_{12}$ $1 \%$, calcium pantothenate, biotin, niacin, folic acid - $80 \%$, copper sulphate pentahydrate, ferrous sulphate, manganese sulfate, calcium iodate monohydrate, zinc sulfate monohydrate, sodium selenite. **Particle size above $100 \mathrm{~nm}$ GMD. 
Table 2. Ingredients and chemical composition of concentrate for piglets

\begin{tabular}{|c|c|c|c|}
\hline \multicolumn{2}{|l|}{ Ingredients of concentrate } & \multicolumn{2}{|c|}{$\mathrm{g} / \mathrm{kg}$} \\
\hline Whey partially demineralized, spray dried & & \multicolumn{2}{|c|}{450.00} \\
\hline Soybean, micronized processed at $90^{\circ} \mathrm{C}$ & & \multicolumn{2}{|c|}{168.75} \\
\hline Soybean meal, ground & & \multicolumn{2}{|c|}{137.50} \\
\hline Supplement (as shown in Table 1) & & \multicolumn{2}{|c|}{112.50} \\
\hline Yeast, spray dried & & \multicolumn{2}{|c|}{81.25} \\
\hline Blood plasma, spray dried & & \multicolumn{2}{|c|}{50.00} \\
\hline Chemical composition $(\mathrm{kg})$ & T1, T4 and T5 & $\mathrm{T} 2$ & T3 \\
\hline Moisture, & 50.86 & 50.85 & 50.87 \\
\hline Metabolizable Energy, Kcal & 3400 & 3400 & 3400 \\
\hline Crude Protein, g & 299.64 & 299.55 & 299.74 \\
\hline Dairy Protein, $\mathrm{g}$ & 54.35 & 54.35 & 54.35 \\
\hline Lactose, $\mathrm{g}$ & 324.00 & 324.00 & 324.00 \\
\hline Ether Extract, g & 44.72 & 44.72 & 44.71 \\
\hline Crude Fiber, g & 13.01 & 13.05 & 12.97 \\
\hline Mineral Residue, $g$ & 106.08 & 106.15 & 106.01 \\
\hline Calcium, g & 20.00 & 20.00 & 20.00 \\
\hline Available Phosphorus, g & 11.75 & 11.75 & 11.75 \\
\hline Lysine total/digestible, $\mathrm{g}$ & $27.95 / 26.75$ & $27.95 / 26.75$ & $27.96 / 26.75$ \\
\hline Methionine total/digestible, $\mathrm{g}$ & $9.33 / 9.21$ & $9.33 / 9.22$ & $9.33 / 9.21$ \\
\hline Threonine total/digestible, $\mathrm{g}$ & $17.0 / 16.4$ & $17.0 / 16.4$ & $17.00 / 16.4$ \\
\hline Tryptophan total/digestible, $\mathrm{g}$ & $4.58 / 4.05$ & $4.58 / 4.05$ & $4.58 / 4.05$ \\
\hline Valine total/digestible, $\mathrm{g}$ & $12.74 / 11.62$ & $12.73 / 11.62$ & $12.74 / 11.62$ \\
\hline Met+Cys total/digestible, $\mathrm{g}$ & $13.68 / 13.60$ & $13.68 / 13.60$ & $13.68 / 13.60$ \\
\hline Sodium, $g$ & 6.25 & 6.25 & 6.25 \\
\hline Copper, mg & 50.00 & 52.50 & 47.50 \\
\hline Zinc, mg & 6250.00 & 6250.00 & 6250.00 \\
\hline Chromium, $\mu \mathrm{g}$ & 499.99 & 499.99 & 499.99 \\
\hline Selenium organic, mg & 0.375 & 0.394 & 0.356 \\
\hline Vitamin A, IU & 37500.0 & 39375.0 & 35625.0 \\
\hline Biotin, $\mu \mathrm{g}$ & 250.00 & 262.50 & 237.50 \\
\hline Choline, mg & 875.00 & 875.00 & 875.00 \\
\hline Density, g/l & 578.520 & 578.398 & 578.642 \\
\hline
\end{tabular}

Met+Cys: Methionine + Cystine.

The characterization of the concentrate's stability during the shelf life was performed using four parameters: water activity, count of viable aerobic mesophilic microorganisms, evolution of the ether extract concentration, and acidity index. The sampling procedures were performed according to the recommendations of the Guide of the Brazilian Compendium of Animal Feed (Compêndio..., 2013), in accordance with The Codex General Guidelines on Sampling (Codex..., 2004). The water activity (Aw) was evaluated using the Aqua Lab Series 3TE Water Activity Meter equipment (Decagon Devices, Pullman, Washington State, USA). Duplicate analyzes were carried out following the standard operating procedure for series 3TE model in a feed laboratory belonging to the business complex that operates the feed industry. The evaluations were carried out monthly on samples of the five treatments stored in the three locations. Microbiological evaluations of the concentrates stored in Chapecó were performed by counting viable aerobic mesophilic microorganisms. The technique used was the plate in-depth count (PCA - Standard Agar for Counting) incubated at $37^{\circ} \mathrm{C}$ for 48 hours according to AOAC (Official..., 2016). The counts were performed in a colony counter according to the standard technique. The mean number of colonies counted in duplicate plates multiplied by the dilution factor of the corresponding samples provided the number of mesophilic microorganisms per gram of sample. This microbiological evaluation was carried out in the feed analysis laboratory (SENAI/Chapecó, Brazil) on days 0, 45, 90, and 120 after the concentrates were produced and the results were 
expressed in $\log _{10} \mathrm{CFU} / \mathrm{g}$ of sample. Treatment sampling for each collection day was carried out in exclusive bags which were always intact. In each sample collection, a visual evaluation was performed to verify and to confirm the physical stability of the concentrate. The evolution of the ether extract was analyzed according of the Guide of the Brazilian Compendium of Animal Feed (Compêndio..., 2013), which is equivalent to the AOAC (Official..., 2006). The evolution of the acidity index in the concentrate was determined, always in triplicate, using the Compendium (Compêndio..., 2013) method and represented the amount of a strong base ( $\mathrm{mg}$ of $\mathrm{KOH}$ or $\mathrm{NaOH}$ in a concentration of $0.1 \mathrm{M}$ ) that reacted to neutralize free fatty acids (FFA) per gram of sample (methodology equivalent to AOCS (2017) Ca 5a40 applicable to all crude or refined vegetable oils and animal fats).

Fortnightly, during the 120 shelf days of the concentrates, $300 \mathrm{~g}$ samples were collected from bags in each treatment in the storage places for conventional chemical analysis of moisture, crude protein, ether extract, crude fiber, mineral residue, in addition to calcium and phosphorus (Compêndio..., 2013).

$300 \mathrm{~g}$ samples were collected on the day of production and every fifteen days of shelf for mineral analysis by Atomic Absorption Spectrophotometry via Inductively Coupled Argon Plasma (ICP) according to Compendium (Compêndio..., 2013) corresponding to the method AOAC 985.01 (Official..., 2006) ICP/OES (Inductively Coupled Plasma/Optical Emission Spectroscopy). In an outsourced laboratory certified by the National Institute of Metrology, Quality and Technology (INMETRO) to ABNT NBR ISO/IEC 17025:2017 (Associação..., 2017), the minerals Copper $(\mathrm{Cu})$, Iron $(\mathrm{Fe})$, Manganese (Mn), Zinc ( $\mathrm{Zn})$, Selenium (Se), Chromium (Cr), Sodium (Na), Magnesium $(\mathrm{Mg})$, and Potassium $(\mathrm{K})$ were analyzed.

The percentages of the absolute difference between the calculated and the observed values of the evaluated nutrients were calculated. The means of the percentages of the absolute difference (disregarding the value of shelf day 0 ), by treatment and storage place, were calculated, with the storage place considered as repetition. These means were subjected to analysis of variance for the model containing the treatment, storage place and shelf life effects. The details of the treatment and storage place effect were performed using the Tukey test for multiple comparisons of means, whenever the $\mathrm{F}$ test detected a significant effect $(\mathrm{P} \leq 0.05)$. When the effect of shelf life was significant $(\mathrm{P} \leq 0.05)$ regression analysis was performed. The analyzes were performed using the GLM procedure of the SAS (SAS, 2012).

The model evaluated in the variance analysis was:

$\mathrm{Y}_{\mathrm{ijl}}=\mu+\alpha \mathrm{i}+\beta \mathrm{j}+\gamma 1+\varepsilon \mathrm{ij} 1$

Meaning: $Y_{i j l}$ is the mean of the percentage of the absolute difference between the calculated value and the observed value of the i-th treatment with the $\mathrm{j}$-th storage place and the 1-th shelf life; $\mu$ is the fixed effect of the overall mean; $\alpha i$ is the effect of the $\mathrm{i}$-th treatment; $\beta \mathrm{j}$ is the effect of the $\mathrm{j}$-th storage place; $\gamma \mathrm{l}$ is the effect of the l-th shelf life; eijl is the experimental error, supposed to be random, normal, homoscedastic and independently distributed. To evaluate the effect of treatments on the percentage of samples within the guaranteed levels, Fischer's Exact Test was applied.

\section{RESULTS}

Climatic data of the storage places during the experimental period was shown in Tab. 3 .

It was observed that the highest mean temperature recorded was in SGO $\left(27.19 \pm 0.2949^{\circ} \mathrm{C}\right)$, while the highest mean air relative humidity (ARH) was in Araquari $(80.88 \pm 0.937 \%)$, with the lowest mean temperature (Fig. 1). In Araquari, the highest mean temperature and ARH were observed in January. In Chapecó, the highest mean temperature was observed in January and the highest mean for ARH was observed in March. In SGO, the highest means for temperature and ARH occurred in March. Considering the concentrate mixing date, the more extreme conditions were observed, in the different storage places, in the first month (Araquari) or the third month (SGO). In Chapecó, the highest mean values were observed in the first month (temperature) or the third month (ARH), and, in this case, the two parameters did not present maximum expression at the same time (Fig. 1). 
Table 3. Climatic data of the storage places where the concentrates for piglets were distributed for stability evaluation

\begin{tabular}{|c|c|c|c|}
\hline Parameter & Chapecó-SC & Araquari-SC & SGO-MS \\
\hline Location, coordinates & $27^{\circ} 05^{\prime} 47^{\prime \prime} \mathrm{S}$ & $26^{\circ} 22^{\prime} 12^{\prime \prime} \mathrm{S}$ & $19^{\circ} 23^{\prime} 37^{\prime \prime} \mathrm{S}$ \\
\hline (after WGS 84) & $52^{\circ} 37^{\prime} 05 ” \mathrm{~W}$ & $48^{\circ} 43^{\prime} 20^{\prime \prime} \mathrm{W}$ & $54^{\circ} 33^{\prime} 49^{\prime \prime} \mathrm{W}$ \\
\hline Altitude, m (asl, GTOPO30) & 668 & 9 & 609 \\
\hline Distance from industry, $\mathrm{km}$ & 1.0 & 530 & 1180 \\
\hline Mean duration of transport, hours & 0.1 & 8.2 & 17.0 \\
\hline Annual mean temperature, ${ }^{\circ} \mathrm{C}$ & 18.9 & 21.1 & 23.3 \\
\hline Mean annual rainfall, $\mathrm{mm}$ & 1997 & 1745 & 1507 \\
\hline Climate $^{1}$ & $\mathrm{Cfa}$ & $\mathrm{Cfa}$ & Aw \\
\hline \multicolumn{4}{|l|}{ Mean monthly data (4-month period) } \\
\hline Mean temperature, ${ }^{\circ} \mathrm{C}$ & 20.7 & 24 & 24 \\
\hline Minimum temperature, ${ }^{\circ} \mathrm{C}$ & 15.5 & 20 & 18.7 \\
\hline Maximum temperature, ${ }^{\circ} \mathrm{C}$ & 25.9 & 28 & 29.5 \\
\hline Rainfall, mm & 160 & 206 & 180 \\
\hline
\end{tabular}

SC: Santa Catarina; SGO: São Gabriel do Oeste; MS: Mato Grosso do Sul; ${ }^{1}$ according Köppen and Geiger (1928); Cfa = Humid subtropical climate; Aw: Savannah tropical climate.

The weekly means of the maximum air relative humidity (ARHMAX) and maximum temperature (TEMPMAX) demonstrated that in Araquari a constant climate prevailed, with low TEMPMAX (daytime mean of $24.8^{\circ} \mathrm{C}$ in the four months) and ARHMAX with intermediate value. The weekly means of the daily thermal amplitude and the ARH amplitude in Araquari, during the period, were $2.1^{\circ} \mathrm{C}$ and $3.6 \%$, respectively. In the period,
Chapecó presented a high TEMPMAX, identical to SGO in the first month of shelf, however, it was distinguished from that place, because it had low ARHMAX values. The weekly means of the daily thermal amplitude and the ARH amplitude in Chapecó, during the period, were $5.7^{\circ} \mathrm{C}$ and $13.9 \%$, respectively, while the weekly mean of the daily thermal amplitude was $5.0^{\circ} \mathrm{C}$ and the daily ARH was $26.6 \%$ in SGO.

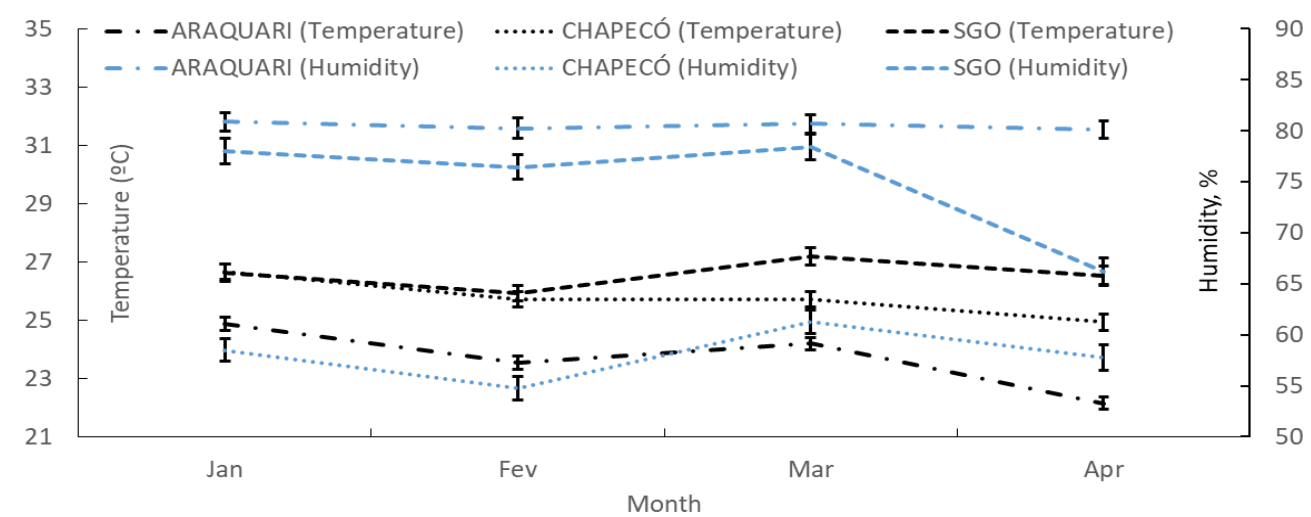

Figure 1. Monthly mean temperature and air relative humidity in the three storage places of the concentrate for piglet.

The Aw was affected by treatment $(\mathrm{P}<0.0001)$, storage place $(\mathrm{P}=0.0257)$ and shelf life $(\mathrm{P}<0.0001)$. The Aw determined in the samples stored in Araquari $(0.4271 \pm 0.00339)$ differed $(\mathrm{P}<0.05)$ of the samples from SGO $(0.4158 \pm 0.00339)$. The Aw of the samples stored in Chapecó $(0.4203 \pm 0.00285)$ presented a mean value intermediate to the two other storage places $(\mathrm{P}>0.05)$. Despite the environmental conditions and evolution of the Aw values, there was no consequence or effect on the visual alteration of the mixtures.

In the evaluated period, Aw presented a negative correlation with the mean temperature and the mean TEMPMAX ( $\mathrm{r}=-0.8404$ and $\mathrm{r}=-0.9363$, respectively), indicating that, together with the variation in the ambient temperature over the storage period, occurred an inevitable increase in the Aw values. 
It was verified an increase $(\mathrm{P}<0.05)$ in the Aw values according to the days of shelf life (Fig. 2). The Aw increased from the lowest value in the sample collected after preparing the concentrate $(0.375 \pm 0.009)$ to the maximum shelf life of 120 days $(0.458 \pm 0.003)$. It was observed an increase of $10.93 \%$ in the Aw in the first 30 shelf days [100 $x(0.416-0.375) / 0.375]$, and in the last 30 shelf days, this increase was $5.94 \%$ [100 x $(0.458$ $0.433) / 0.433]$. In the intermediary's shelf life, (60 and 90 days), there was a constant increase less pronounced (1.68\% and $2.31 \%$, respectively).
The PXMore5 and PXLess5 treatments did not differ $(\mathrm{P}>0.05)$ from the Control treatment for any of the evaluated parameters presented in Tab. 4. The Aw and moisture results of the FeedMixer treatment differed from the others, however, this difference did not represent a risk of alteration. The maximum acceptable moisture for the concentrate is $10 \%$ and the Aw found did not contribute to the development of fungi and bacteria (Fig. 3).

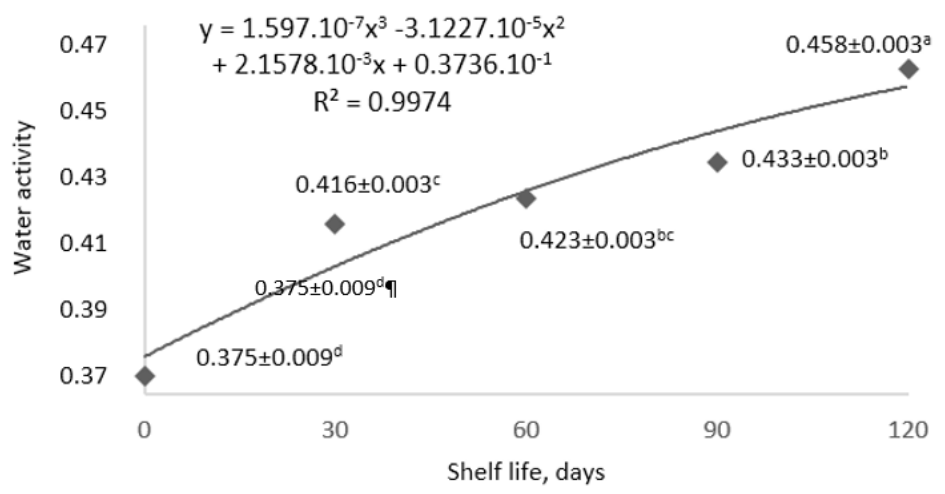

Figure 2. Water activity $(\mathrm{P}<0.0001)$ according to shelf life of the concentrate for piglet.

Table 4. Mean values of water activity, moisture, acidity, crude protein (CP), and ether extract (EE) according to the treatments

\begin{tabular}{lccccc} 
Treatment & Aw & Moisture, g/kg & $\begin{array}{c}\text { Acidity, mg } \\
\text { NaOH/g }\end{array}$ & CP, g/kg & EE, g/kg \\
\hline Control & $0.4145 \mathrm{~b}$ & $48.06 \mathrm{~b}$ & $2.16 \mathrm{~b}$ & $260.8 \mathrm{ab}$ & 44.1 \\
PXMore5 & $0.4170 \mathrm{~b}$ & $47.68 \mathrm{~b}$ & $2.07 \mathrm{~b}$ & $260.9 \mathrm{ab}$ & 44.9 \\
PXLess5 & $0.4189 \mathrm{~b}$ & $48.83 \mathrm{~b}$ & $2.07 \mathrm{~b}$ & $264.3 \mathrm{a}$ & 44.8 \\
FeedMixer & $0.4446 \mathrm{a}$ & $51.92 \mathrm{a}$ & $2.25 \mathrm{~b}$ & $258.6 \mathrm{~b}$ & 43.6 \\
PremixMixer & $0.4103 \mathrm{~b}$ & $48.01 \mathrm{~b}$ & $3.08 \mathrm{a}$ & $232.0 \mathrm{c}$ & 45.2 \\
\hline SEM & 0.00486 & 0.452 & 5.66 & 1.338 & 5.96 \\
Pr $>$ F & $<0.0001$ & $<0.0001$ & $<0.0001$ & $<0.0001$ & 0.3011 \\
\hline
\end{tabular}

SEM: standard error of the mean; Pr $>$ F: probability; Aw: water activity; Means followed by distinct letters in the column differ by Tukey's test $(\mathrm{P} \leq 0.05)$.

The correlation between Aw and moisture was high $(\mathrm{r}=0.9681)$, and it indicated that alterations, even low in the moisture values, present a direct relation with the concentrate stability through the Aw. In the evaluated interval, each $1 \%$ increase in moisture generated an increase of 0.128 units in Aw. The Aw values of the concentrate for the five treatments stored in the three different places and at the level of Aw detected makes it difficult to develop fungi and mycotoxins after uniform mixing of all the ingredients composing the concentrate. Furthermore, the development of fungi, yeasts, and bacteria was compromised in the Aw range (0.375 to 0.458$)$ that was detected during the 120 days of shelf life. This was corroborated by the results obtained in determining the number of colony-forming units of viable aerobic mesophiles that present the development of bacteria in the optimal temperature range of 35 to $36^{\circ} \mathrm{C}$. In viable aerobic mesophiles counts, there was a significant drop in concentration $(\mathrm{P}=0.0042)$ with increasing shelf life (Fig. 3). 


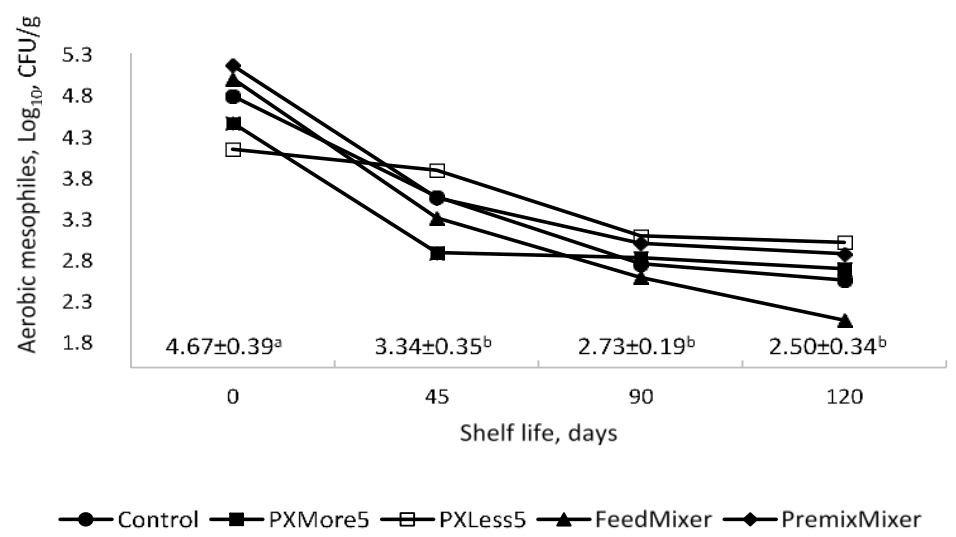

Figure 3. Viable aerobic mesophiles $(\mathrm{P}=0.0042)$ according to shelf life of the concentrate for piglet.

For the acidity parameter, the PremixMixer treatment obtained a higher index than the others $(3.08 \pm 5.66 \mathrm{mg} \mathrm{NaOH} / \mathrm{g} ; \mathrm{P}<0.05)$, however, there was still no safe and defined and/or recommended acidity limit for the concentrate (Table 4). Similarly, this treatment showed a lower crude protein concentration $(232.0 \pm 1.338 \mathrm{~g} / \mathrm{kg} ; \mathrm{P}<0.05)$ than the other treatments. There was a strong negative correlation $(r=-0.9951)$ between the acidity index and the crude protein, indicating that some ingredient used in the concentrate with a low protein concentration, suspected to be a dairy product, has a high capacity to increase the acidity index. The greater or lesser presence of this ingredient in the concentrate may interfere with the acidity index and crude protein in an antagonistic way. The routine quality control carried out on the ingredients allows the relative contribution to acidity to be calculated based on the level of inclusion in the concentrate (Table 5). In this respect, whey powder has a high relative contribution to acidity and low contribution to protein. The concentrate has an acidifying additive in its composition that can make the $\mathrm{pH}$ acid, and it demands a base to neutralize in the analysis. Therefore, following the routine quality control data for acidity and $\mathrm{pH}$, in representative batches of concentrates with identical composition, an acidity index of $2.720 \mathrm{mg}$ $\mathrm{NaOH} / \mathrm{g}$ and $\mathrm{pH}=6.25$ was verified. These were intrinsic conditions of the concentrate that were the reference for all five treatments.

The crude protein of the PXLess5 treatment $(264.3 \pm 1.338 \mathrm{~g} / \mathrm{kg})$ differed $(\mathrm{P}<0.05)$ from the FeedMixer $(258.6 \pm 1.338 \mathrm{~g} / \mathrm{kg})$ which, in turn, differed $(\mathrm{P}<0.05)$ from the PremixMixer $(232.0 \pm 1.338 \mathrm{~g} / \mathrm{kg})$. The desired percentage was at least $216 \mathrm{~g} / \mathrm{kg}$, and all treatments showed a higher percentage. The PremixMixer treatment presented the result closest to the established limit.

Table 5. Percentage of the relative contribution of the ingredients on parameters, based on previous quality control before mixing the concentrates for piglets

\begin{tabular}{lcccccc} 
Parameter, \% & $\begin{array}{c}\text { Soybean } \\
\text { meal }\end{array}$ & $\begin{array}{c}\text { Micronized } \\
\text { Soybean }\end{array}$ & $\begin{array}{c}\text { Spray- } \\
\text { dried } \\
\text { Whey }\end{array}$ & $\begin{array}{c}\text { Spray- } \\
\text { dried } \\
\text { Plasma }\end{array}$ & $\begin{array}{c}\text { Spray- } \\
\text { dried } \\
\text { Yeast }\end{array}$ & Supplement \\
\hline Inclusion level & 13.75 & 16.88 & 45.00 & 5.00 & 8.13 & 11.25 \\
Moisture & 37.86 & 15.15 & 25.80 & 6.66 & 4.7 & 9.83 \\
Acidity & 3.54 & 22.32 & 70.05 & 0.29 & 3.8 & NA \\
Water activity & 23.1 & 13.4 & 39.0 & 3.2 & 6.1 & 15.2 \\
Ether extract & 4.29 & 90.90 & 2.05 & - & 0.09 & 2.66 \\
Crude protein & 23.8 & 23.88 & 19.81 & 15.73 & 7.04 & 9.75 \\
Crude fiber & 36.11 & 49.32 & 6.68 & - & 0.4 & 7.89 \\
Mineral residue & 7.61 & 8.07 & 20.94 & 3.68 & 2.78 & 56.92 \\
Calcium & 2.52 & 2.43 & 15.99 & 0.36 & 0.58 & 78.53 \\
Phosphorus & 9.59 & 9.91 & 25.42 & 8.03 & 0.45 & 46.60 \\
\hline
\end{tabular}

NA - Without analysis 
Analyzing the ether extract, all treatments reached the indicated percentage of presenting at least $35 \mathrm{~g} / \mathrm{kg}$, and the concentrations did not differ between treatments $(\mathrm{P}=0.3011)$. The relative contribution of each of the main ingredients to the stability of the concentrates presented in Table 5 was based on the quality control analyses. The Aw was 0.338 for spray-dried whey, 0.309 for micronized soybean, 0.653 for soybean meals, 0.526 for the supplement, 0.248 for spray-dried plasma, and 0.295 for spray-dried yeast. The acidity index (mg de $\mathrm{NaOH} / \mathrm{g}$ ) was 1.33 for spraydried whey, 1.13 for micronized soybean, 0.22 for soybean meals, 0.05 for spray-dried plasma, and 0.40 for spray-dried yeast. The moisture was $2.44 \%$ for spray-dried whey, $3.82 \%$ for micronized soybean, $11.72 \%$ for soybean meals, $3.72 \%$ for the supplement, $5.67 \%$ for spray-dried plasma, and $2.46 \%$ for spray-dried yeast. Soy products, despite comprising only $30.65 \%$ of the ingredients in the concentrate, were responsible for $95.2 \%$ of the ether extract, $85.4 \%$ of crude fiber, $53.0 \%$ of moisture, $47.7 \%$ of crude protein, $36.4 \%$ of water activity, and $25.9 \%$ of acidity.

Considering the shelf life, the analysis indicated that, as the days advanced, the value of the lipid compounds changed, showing an increase of $2.45 \%$ (from 44.8 to $45.9 \mathrm{~g} / \mathrm{kg}$ ) up to 39 days of shelf life of the concentrate (Fig. 4). The determined values of the lipid compounds reflect the instability and transformation dynamics of the fats present in the concentrate. The reduction in the concentration of lipid compounds in the total 120 -day shelf life was $8.1 \%$. From the maximum value estimated for 39 days of shelf by the established equation (the predicted maximum oxidation) until the end of the shelf life, there was a difference of $11.4 \%$.

In addition to the change in the concentration of lipid compounds, simultaneously, the acidity of the concentrate was also changed. Lipid oxidation was measured using the lipid peroxidation level and estimated using the acidity index. Initially, there was a marked drop until 48 days after making the concentrate (Fig. 4). At this point, the acidity reached the minimum estimated value, stabilizing in $2.12 \pm 6.54 \mathrm{mg} \mathrm{NAOH} / \mathrm{g}$ (Fig. 5). After 48 days, the estimated acidity value increased until reaching $2.23 \pm 6.54 \mathrm{mg} \mathrm{NAOH} / \mathrm{g}$ at the end of the evaluation period. There were three defined periods in the evolution index: a) up to 48 days, initial period, in which there is a marked reduction in the value of acidity; 2) from 49 to 84 days, intermediate period, in which an increase was estimated in the evolution rate of the acidity value, and c) final period, from 85 to 120 days, in which there was the slowdown in the evolution rate of the acidity index. It is important to note that the mean value of representative acidity at 120 days was lower $(\mathrm{P}<0.0001)$ than the mean value observed on the day of the concentrate production, with a reduction of $3.46 \%$.

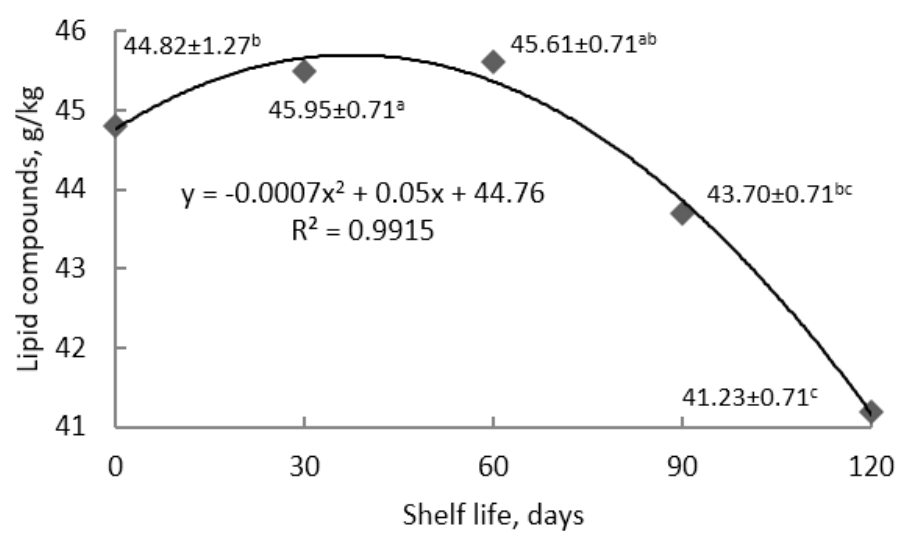

Figure 4. Lipid compound concentration $(\mathrm{P}<0.0001)$ according to the shelf life of the concentrate for piglets. 


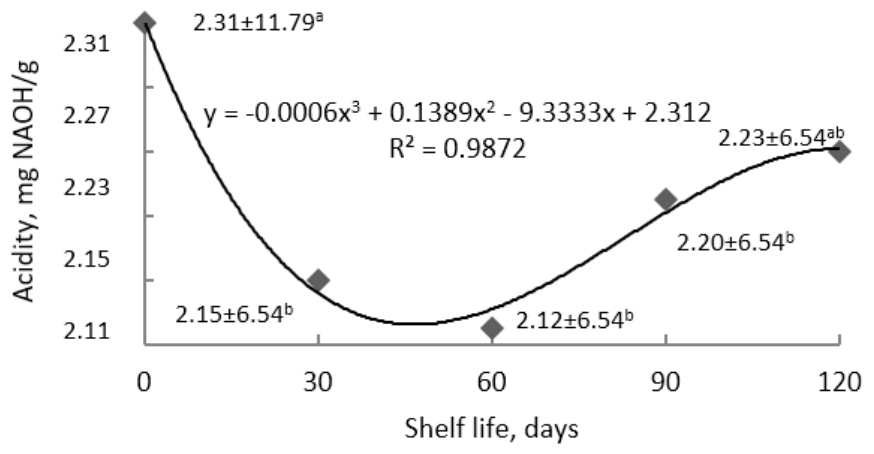

Figure 5. Acidity $(\mathrm{P}<0.0001)$ according to the shelf life of the concentrate for piglet.

A negative correlation was established between the concentration of lipid components and acidity, which was calculated considering the evolution of the values according to the shelf life. This may indicate that in established shelf life, the increase in the concentration of lipid compounds coincided with a simultaneous non-availability or neutralization of the radicals generated through autocatalytic lipid oxidation reactions, reducing the demand for bases (correlation in the period from 1 to 48 days of -0.9956 ). In the periods between 49 to 84 days, and 85 to 120 days, the correlations were -0.9995 and -0.9646 , respectively. In the stage when the lipid compounds concentration was reduced, with the formation and decomposition of free fatty acids, there was a greater demand for bases to neutralize the compounds formed.

The correlation between chromium and selenium $(\mathrm{r}=-0.9197)$, chromium and copper $(\mathrm{r}=-0.8922)$ and chromium and zinc ( $\mathrm{r}=-0.9192)$ was negative and high, showing that chromium presents a technological challenge, as for maximum uniformity in the parameters, chromium will present a high variation in its concentration. Therefore, some technological tool must be adopted to minimize these occurrences.

\section{DISCUSSION}

The results of Aw and moisture showed that the FeedMixer treatment differed from the others, therefore, since the maximum acceptable moisture for the product is $10 \%$ the Aw observed does not allow the development of fungi and bacteria. According to Garcia (2004), the minimum value of Aw for fungal growth is 0.78 and for aflatoxin production is 0.86 .
The changes in water activity, in the count of viable aerobic mesophiles, in the content of lipid compounds, and acidity indicate a simultaneous and integrated evolution of the concentrates stability when evaluated in the different storage places and over the time of shelf. The four parameters evaluated were related to each other because they were measured on the concentrates that were considered metastable dynamic and complex systems. However, the correlation was not always evidence of a cause-and-effect relationship (Slade et al., 1991).

Araquari-SC, the storage place with the environment with greater climatic uniformity (with lower amplitude in air relative humidity and daytime temperatures) presented the highest final value of Aw, probably influenced by a high and constant air relative humidity. São Gabriel do Oeste-MS, the storage place with the greatest climatic variation had the lowest Aw, although the daily mean of the maximum air relative humidity was higher. In general, the evolution in Aw with the shelf life shows an increase of $22.1 \%$, comparing the beginning and the end of the evaluation period, but this evolution was not constant in the period, being more intense in the first and last months.

The Aw is related to the potential of microbiologic development and the potential of oxidation of the components present in the concentrates. Accurate knowledge of Aw values, sorption isotherms and humidity is important because it is related to the stability of macro-ingredients, synthetic amino acids, supplements, and additives that interact when uniformly mixed in rations and concentrates (Tavernari et al., 2017). Controlling the intrinsic conditions of the ingredients and the 
environmental conditions of storage, the microbiological, enzymatic, or chemical deterioration reactions are minimized.

Bacteria, yeasts, and fungi are nutrient-dependent, $\mathrm{pH}$-sensitive, respond to the presence of oxygen, temperature variation, and free water concentration (On-farm..., 2007). The preferred substrates for bacteria are proteins while for fungi and yeasts the preferred substrates are sugars and starch. Opposite to bacteria and yeasts, fungi are less sensitive to low concentrations of available free water. If the substrate presents humidity between 10 and $15 \%$, and Aw between 0.65 and 0.80 , there is a potential to develop some fungi genres, such as Penicillium, Aspergillus, and Monascus. The minimum Aw value for yeasts is 0.81 and for bacteria 0.86 , and below the value of 0.6 there is no possibility of deterioration because the water present in the substrate is linked to protein and carbohydrate molecules (Beuchat, 1981; Beuchat et al. 2013). Salmonella sp. develops in Aw from 0.92 to 0.95 (Beuchat, 1981). This knowledge indicates the conditions in which food products must be stored to increase shelf life and serve as a control parameter during food processing, as each food has an optimal value of Aw where microbiological, enzymatic or chemical substances are minimized (Garcia, 2004).

Aerobic colony count (ACC) is a quality indicator that can provide useful information on general quality and shelf life and may be related to possible storage and handling problems since production. The plate counting technique of aerobic mesophilic bacteria was commonly used to indicate the sanitary quality of the food, because even if the pathogens were absent and there have been no changes in the sensory characteristics of the food, a number above $10^{6}$ $\mathrm{CFU} / \mathrm{g}$, indicated that the food was unhealthy (Forsythe, 2020).

The values obtained in the evaluation of viable aerobic mesophiles in this study was adequate in concentrates for feeding piglets as recommended by Cabarkapa et al. (2009) and Nesic et al. (2020). Thus, for all treatments during the shelf life period, each one of the values of aerobic mesophilic colony-forming units was classified as normal according to the classification established by the VDLUFA method for this quality category. The characteristic of the VDLUFA method was that the microbiological safety of animal feed considered not only the total number of microorganisms (CFU/g) but also the potential for pathogenicity (Zadravec et al., 2015).

In the evaluation performed during the shelf life, the effect in reducing the count of viable aerobic mesophilic cells reflects their relatively high initial concentration in the ingredients of plant and animal origin used in the concentrate's formulation. The result of the decline was still associated with the saline index of mineral products, the intrinsic properties of some ingredients, and the stabilizing products that offer unfavorable conditions for the formation of colonies and help in their degradation processes. However, a primary factor must be the consumption and depletion of oxygen present in concentrates packed in hermetically sealed packages.

The maximum increase in the concentration of lipid compounds was $2.45 \%$ at 39 days of shelf. This value was compatible with the oxidation dynamics and indirectly reflects the course of the oxidation process. Different free fatty acids (FFA) had a different propensity in the oxidation rate, and, for example, 20-carbon polyunsaturated fatty acids react 250 times faster than 18-carbon polyunsaturated fatty acids (Bortone and Mann, 2006). In this study, a relative contribution of $95.2 \%$ for the ether extract (EE) was calculated in the concentrates using soy-based products. According to Rostagno et al. (2017), oil from soybased ingredients had on the mean, a concentration of $23.32 \%$ of $\mathrm{C} 18: 1 ; 52.78 \%$ of C18:2; $6.97 \%$ of $\mathrm{C} 18: 3$, and $2.13 \%$ fatty acids with 20 carbons.

When evaluating the concentration of lipid compounds during oxidation, at the shelf life of 120 days, a reduction in the concentration of $8.1 \%$ was observed, which, in addition to oxidative decomposition, can also be partially attributed to the glycerol fraction released in the formation of FFA. Lipase enzymes, in the presence of factors predisposing to oxidation (humidity, temperature, oxygen, and minerals) hydrolyze fats and release FFA which were broken down into byproducts characteristic of rancidity and of which many were volatile. Mendes et al. (2014) also found changes in EE levels over the course of 60 days due to the contact of freely exposed ration causing an acceleration in the oxidation process of the 
lipids and justifying the lower concentration of EE in the ration of cats after continued exposure to the environment.

The lipolytic rancidity caused by the hydrolysis of the ester bond of lipids by enzymes or chemical agent in the presence of humidity was estimated through the acidity index (AI), which quantitatively evaluates the degree of deterioration, whose expression was milligrams of a base $(\mathrm{KOH}$ or $\mathrm{NaOH})$ needed to neutralize the FFA in one gram of sample. The maximum values allowed in fats and animal by-products vary from 2 to $3 \mathrm{mg} \mathrm{NaOH} / \mathrm{g}$ (Bellaver and Zanotto, 2004). Only a trace amount $(<50 \mathrm{ppb})$ of iron was needed to break down hydroperoxides to free radicals. Studies showed that peroxides were broken down into aldehydes, ketones, alcohols, hydrocarbons, esters, furans, and lactones, causing the loss of the quality of oils and fats present in food, even when subjected to an ambient temperature of $25 \pm 2^{\circ} \mathrm{C}$ (O’Brien, 2004; Van Eys, 2015).

The acidity evolution (expressed in $\mathrm{NaOH} / \mathrm{g}$ ) is an indirect and dynamic indicator that represents the balance between the presence and decomposition of FFA, in addition to accounting for all other potential compounds generated in the process that even include the formation of hydroxyls. In this way, the drop in the amount of base $(\mathrm{NaOH})$ necessary to determine an acid value of the concentrates, which was estimated through an equation and reached the minimum value at 48 days, should represent the evolution of the balance of chemical reactions that occur in this initial period. Most likely, the magnitude of the variation in values is influenced by the balance between hydroxyl generation and consumption.

Nutrients such as iron and copper present in ingredients and added to concentrates have several possible oxidation states that allow participation in the electron transfer process. In this initial phase, the Fenton chemical reaction continuously modifies the elements $\mathrm{Fe}^{+2}$ and $\mathrm{Cu}^{+2}$ to $\mathrm{Fe}^{+3}$ and $\mathrm{Cu}^{+3}$, and at the same time generates hydroxyls in an intense process of very reactive reactions. Additionally, in the oxidative value of the concentrates, which was estimated through an equation and reached the minimum value at 48 days, should represent the evolution of the balance of chemical reactions that occur in this initial period. Most likely, the magnitude of the variation in the values was influenced by the balance between hydroxyl generation and consumption. processes, hydroxyl generation also occurs through the Haber-Weiss reaction complementing the concentration (Gutowski and Kowalczyk, 2013).

A second moment, characterized between 49 and 84 days, is a period in which the estimated acidity assumes increasing values. At this moment, there is a balance between the spread of oxidation induced by the presence of oxidized metals, which according to Ahmed et al. (2016) had a slow reaction. In this process, the hydroxyl concentration is reduced, while $\mathrm{Fe}^{+3}$ (or $\mathrm{Cu}^{+3}$ ) changes to $\mathrm{Fe}^{+2}$ (or $\mathrm{Cu}^{+2}$ ), generating an acid environment by the $\mathrm{H}^{+}$production. The $\mathrm{Fe}^{+3}$ is 100 times less soluble than the $\mathrm{Fe}^{+2}$ under conditions of $\mathrm{pH}$ closer to neutral, however, in an environment with a more acid $\mathrm{pH}$, the reactions were more favorable (Ferreira and Matsubara, 1997). Thus, the maximum decomposition of the lipid components must occur between pH 5.0 to 5.5. Araújo et al. (2016) found a high negative correlation ( $r=-0.781)$ between the acidity in the soybean and the ether extract content.

In the final stage of the concentrate's shelf life, between 85 and 120 days, it was possible to estimate a tendency to stabilize the acidity value. This stabilization does not represent the stability of the concentrates because it indicates that a new equilibrium in the generation occurs between concentrations of $\mathrm{OH}^{-}$e $\mathrm{H}^{+}$and not that oxidation reactions ceased. At 120 days, the acidity index was $3.6 \%$ lower than the initial value just after concentrates production. However, when related to the EE concentration at 120 days, the acidity index had a proportional increase of $4.7 \%$, indicating that at this moment the concentrates present a less stable situation than at the initial moment of evaluation. According to Frankel (1984, 1993, 2012), to properly evaluate the situation of a given product in terms of oxidation, it was necessary to establish a sequence of analyzes to monitor the evolution of oxidative processes.

Lopes et al. (2011) evaluated the initial acidity in coconut meal when it arrived at the feed industry for use in laying rations and found an increase of more than $65 \%$ in the acidity index after stored for a period of 35 days. In dog and cat rations, acidity has also increased over time (Mendes et al., 2014). In dog ration, there was stabilization and 
later a small decline in the amount of FFA, however, in cat ration there was a gradual increase. Lopes (2015), using the AOCS (2017) Ca 5a-40 method, determined a wide variation for the acidity index in the range of 0.338 to $3.033 \mathrm{mg}$ of $\mathrm{KOH} / \mathrm{g}$ of oil extracted via Soxhlet with hexane solvent from 25 samples of soybeans. According to Kanner and Rosenthal (1992), the complexity of the chemistry involved in oxidation challenges the possibility of a universal analytical test for the unconditional evaluation of the dynamic process. Thus, the high index of potentially reactive metal ions present in the elaborated concentrate provides a favorable environment for the dynamics of lipid oxidation in complex mixtures composed of proteins, carbohydrates, vitamins, minerals, antioxidants, and stabilizers that present different degrees of stability when they interact in the complex mix.

Only three ingredients were responsible for almost $75.6 \%$ of the concentrate, each of which affects the final stability of the product. Theoretically considering additive effects, whey contributes to $70 \%$ in the acidity index, $39 \%$ in Aw, $26 \%$ in moisture, and $21 \%$ in the mineral residue. The micronized soybean, with the inclusion of $16.87 \%$, contributes with $90.9 \%$ of the EE and $22.3 \%$ with the acidity in the concentrate. While the soy meal, used in the concentration of $13.75 \%$, potentially contributes to $37.9 \%$ of the moisture and $23 \%$ of the Aw in the mixture. The stability of the physical structure of dehydrated whey occurs through the combination of $\mathrm{Aw}, \mathrm{pH}$, temperature, and original structure of lactose in the ratio between amorphous and crystalline structures (Roos, 2002). There were at least eight different forms of lactose and the stability of dairy products depended on a lesser presence of amorphous lactose, which was more unstable (Carpin et al., 2017).

With the standard operating procedure used in this study, the effects on the quality of the mixture, observed through the mineral analysis of the different mixers used, were reduced. It was demonstrated that the monitoring of quality control, as well as its routines, including traceability, makes it possible to visualize a history of recorded information regarding the production of a product. It is a way to ensure the guarantee of the entire production flow, from the quality of the ingredient used to the producer who received the feed for their animals. If any anomaly is observed in a timely manner, recall actions are avoided. Recall processes need precise bases, as they cause high losses, such as: occurrence of product disposal and/or reprocessing; the rejection of food by animals due to organoleptic alterations; harms the yield of the lot; affects the trust of the brand by the customer/consumer.

Increasing (or maintaining) product quality requires rationalization of the production process and constant monitoring to meet the defined quality parameters, aiming at food safety.

\section{CONCLUSIONS}

Changes in lipid concentration and acidity index, the water activity evolution, and the concentration of viable aerobic mesophiles are reflections of the dynamic interaction processes of the ingredients that make up the homogeneously mixed concentrate. Analyzing the storage place, differences in temperature and air relative humidity affected the water activity of the concentrate, however, these changes did not compromise physical stability. Changes in the concentration of viable aerobic mesophiles should depend on the oxygen concentration in the hermetically sealed packaging and on the interactions of the chemical activities of the preservative technological additives employed.

Despite the different environmental conditions identified in the four months of the experimental period and the evolution of Aw values, there was no consequence or practical effect on the visual alteration of the mixtures and there was no demand for recall. Thus, under controlled conditions of product handling, aiming at detailed monitoring in different environments, no effects were observed that would determine the possibility of the occurrence of recall.

\section{ACKNOWLEDGEMENTS}

The authors thank the feed industry for providing the facilities, ingredients used to produce the experimental feed and the laboratory; National Council for Scientific and Technological Development (CNPq, Brazil) and Coordination of Superior Level Staff Improvement (CAPES, Brazil). 


\section{REFERENCES}

AOCS official method Ca $5 \mathrm{a}-40$ - free fatty acids in crude and refined fats and oils. Illinois: AOCS official methods and recommended practices of the AOCS, 2017. Available in: https://www. aocs.org/attain-labservices/methods/methods/search-

results?method=111480\&SSO=True. Accessed in: 29 Jan. 2021.

ASSOCIAÇÃO BRASILEIRA DE NORMAS TÉCNICAS - NBRISO/IEC 17025:2017. Requisitos gerais para a competência de laboratórios de ensaio e calibração. 3.ed. São Paulo: ABNT, 2017. 32p.

AHMED, M.; PICKOVA, J.; AHMAD, T. et al. Oxidation of lipids in foods. Sarhad J. Agric., v.32, p.230-238, 2016.

ARAÚJO, M.M.V.; CANEPPELE, M.A.B.; BIANCHINI, M.G.A. Total alcoholic acidity and $\mathrm{pH}$ tests as quality parameters in stored soybean grains. Pesqui. Agropecu. Trop., v.46, p.191-196, 2016.

BEUCHAT, L.R. Microbial stability as affected by water activity. Cereal Foods World, v.26, p.345-349, 1981.

BEUCHAT, L.R.; KOMITOPOULOU, E.; BECKERS, H. et al. Low-water activity foods: increased concern as vehicles of foodborne pathogens. J. Food Prot., v.76, p.150-172, 2013.

BELlAVER, C.; ZANOTTO, D.L. Parâmetros de qualidade em gordura e subprodutos proteicos de origem animal. In: CONFEREÊNCIA APINCO DE CIÊNCIA E TECNOLOGIA AVÍCOLAS, FACTA, 2004, Santos. Anais...São Paulo: [s.n.] 2004. p.79. (Resumo).

BORTONE, E.; MANN, J. Understanding oxidation: managing ingredient, food quality. Alabama: [s.n.], 2006. Available in: https://www.aquaculturealliance.org/advocate/aquafee ds/ understanding-oxidation-managing-ingredientfood-quality.pdf. Accessed in: 13 Mar. 2020.

BRASIL. Ministério da Agricultura, Pecuária e Abastecimento - MAPA. Instrução Normativa $n^{\circ} .22$ : regulamenta a embalagem, rotulagem e propaganda dos produtos destinados à alimentação animal. Brasília, 2 jun. 2009. Available in: https://www.gov.br/ agricultura/pt-br/assuntos/insumos-agropecuarios/ insumos-pecuarios/alimentacao-animal/arquivosalimentacao-animal/legislacao/instrucao-normativano-22-de-2-de-junho-de-2009.pdf/view. Accessed in: 5 May. 2020.
BRASIL. Ministério da Agricultura, Pecuária e Abastecimento. Instrução Normativa $n^{\circ} 38$ : altera a Instrução Normativa MAPA n ${ }^{\circ} 42$, de 16 de dezembro de 2010, que estabelece critérios e procedimentos para a fabricação, fracionamento, importação e comercialização dos produtos isentos de registro. Brasília, 27 de outubro de 2015.

CABARKAPA, I.; KOKIC, B.; PLAVSIC, D. et al. Microbiological safety of animal feed. J. Anim. Sci. Biotechnol., v.25, p.1155-116, 2009.

CARPIN, M.; BERTELSEN, H.; DALBERG, A. et al. How does particle size influence caking in lactose powder? J. Food Eng., v.209, p.61-67, 2017.

CODEX committee on methods of analysis and sampling. CAC/GL 50-2004 (FAO/WHO, 2004). The Codex General Guidelines on Sampling, 2004. 73p. (Codex Alimentarius.). Available in: https://www.agriculture.gov.au. Accessed in: 15 Mar. 2020.

COMPÊNDIO brasileiro de alimentação animal: métodos analíticos. São Paulo: Sindirações, 2013.

CONEGLIAN, S.M.; LIMA, B.S.; SILVA, L.G. et al. Utilização de antioxidantes nas rações. PubVet., v.5, p.1019-1026, 2011.

FERREIRA, A.L.A.; MATSUBARA, L.S. Radicais livres: conceitos, doenças relacionadas, sistema de defesa e estresse oxidativo. Rev. Assoc. Med. Bras., v.43, p.61-68, 1997.

FORSYTHE, S.J. The microbiology of safe food. 3.ed. Nottingham: John Wiley \& Sons, 2020. 608p.

FRANKEL, E.N. Lipid oxidation: Mechanisms, products and biological significance. J. Am. Oil Chem. Soc., v.61, 1984, p.1908-1917, 1997.

FRANKEL, E.N. In search of better methods to evaluate natural antioxidants and oxidative stability in food lipids. Trends Food Sci. Technol., v.4, p. 220-225, 1993.

FRANKEL, E.N. Lipid oxidation. 2.ed. California: The Oily Press Lipid Library, 2012. 488p.

FRIGO, C.; MIELE, M. Custo de produção de leitões em diferentes sistemas de produção: um estudo de caso no Oeste Catarinense. In: CONGRESSO DA SOCIEDADE BRASILEIRA DE SISTEMAS DE PRODUÇÃO, 10., 2014, Foz do Iguaçu. Anais... Foz do Iguaçu: [s.n.], 2014. p.1345. (Resumo).

GABBI, A.M.; CYPRIANO, L.; PICCININ, I. Aspectos microbiológicos e físico-químicos de três rações comerciais sob diferentes condições de armazenamento. Rev. Bras. Saúde Prod. Anim., v.12, p.784-793, 2011. 
GARCIA, D.M. Análise de atividade de água em alimentos armazenados no interior de granjas de integração avícola. 2004. 50f. Dissertação (Mestrado em Ciências Veterinárias) - Faculdade de Veterinária, Universidade Federal do Rio Grande do Sul, Porto Alegre, RS.

GODDARD, J.M.; MCCLEMENTS, D.J.; DECKER, E.A. Innovative technologies in the control of lipid oxidation. Lipid. Technol., v.24, p.275-277, 2012.

GUTOWSKI, M.; KOWALCZYK, S.A. Study of free radical chemistry: their role and pathophysiological significance. Acta Biochim. Pol., v.60, p.1-16, 2013.

KANNER, J.; ROSENTHAL, I. An assessment of lipid oxidation in foods. Pure Appl. Chem., v.64, p.19591964, 1992.

KERR, B.J.; KELLNER, T.A.; SHURSON, G.C. Characteristics of lipids and their feeding value in swine diets. J. Anim. Sci. Biotechnol., v.6, p.1-23, 2015.

KÖPPEN, W.; GEIGER, R. Klimate der erde. Gotha: Verlag Justus Perthes, 1928. 369p.

LONGO, F.A.; SILVA, I.F.; LANZARIN, M.A. A importância do controle microbiológico em rações para aves. In: SIMPÓSIO BRASIL SUL DE AVICULTURA E 2. BRASIL SUL POULTRY FAIR, 11., 2010, Chapecó. Anais...Chapecó: [s.n.], 2010. p.36. (Resumo).

LOPES, E.L. Estratégias para a caracterização de amostras brasileiras de óleo de soja empregando ATRFTIR e HLPC-ELSD aliadas a ferramentas quimiométricas. 2015. 88f. Dissertação (Mestrado em Química) - Instituto de Química, Universidade Federal do Rio Grande do Sul, Porto Alegre, RS.

LOPES, I.R.V.; FREITAS, E.R.; LIMA, J.R. et al. Desempenho e qualidade dos ovos de poedeiras comerciais alimentadas com rações contendo farelo de coco tratado ou não com antioxidante. Rev. Bras. Zootec., v.40, p.2431-2438, 2011.

MCCOY, R.A.; BEHNKE, K.C.; HANCOCK, J.D. et al. Effect of mixing uniformity on broiler chick performance. Poult. Sci., v.73, p.443-451, 1994.

MENDES, J.V.; PIRES, P.G.S.; TEIXEIRA, L. et al. Avaliação de alimentos secos industrializados para cães e gatos expostos ao ambiente. Enciclop. Biosf., v.10, p.306-318, 2014.

NESIC, K.; PAVLOVIC, M.; IVANOVIC, S. Assessment of the microbiological quality of feed using the Verbands Deutscher Landwirdschaftlicher Untersuchungs und Forschungsanstalten (VDLUFA) method. Vet. Glas., v.74, p.68-76, 2020.
O'BRIEN, R.D. Fat and oils. In: (Ed.). Fats and oils formulating and processing for applications. Boca Raton: CRC Press, 2004. p.175-232.

OFFICIAL methods of analysis of international. 18.ed. Gaithersburg: AOAC International, 2006.

OFFICIAL methods of analysis of international. 20.ed. Washington: AOAC International, 2016.

ON-FARM mycotoxin control in food and feed grain. Good practices for animal feed and livestock. Rome: Training Manual Food and Agricultural Organization of the United Nations, 2007. Available in: https://www.fao.org/3/a1416e/a1416e00.htm. Accessed in: 13 Mar. 2020.

ROOS, Y.H. Importance of glass transition and water activity to spray drying and stability of dairy powders. Le Lait, v.82, p.475-484, 2002.

ROSTAGNO, H.S.; ALBINO, L.F.T.; HANNAS, M.I. et al. Tabelas brasileiras para aves e suínos composição dos alimentos e exigências nutricionais. 4.ed. Viçosa: UFV, 2017. 488p.

SAS INSTITUTE INC. System for Microsoft Windows. Release 9.4. Cary, NC, USA, 2002-2012. (cd-rom).

SLADE, L.; LEVINE, H.; REID, D.S. Beyond water activity: Recent advances based on an alternative approach to the assessment of food quality and safety. Crit. Rev. Food Sci. Nutr., v.30, p.115-360, 1991.

SHURSON, G.C.; KERR, B.J.; HANSON, A.R. Evaluating the quality of feed fats and oils and their effects on pig growth performance. J. Anim. Sci. Biotechnol. v.6, p.1-11, 2015.

TAVERNARI, F.C.; SORDI, C.; SUREK, D. et al. Isotermas de adsorção de matérias primas e rações para matrizes de postura. Concórdia: Embrapa, 2017. 11p.( Comunicado Técnico 547).

VAN EYS, J.E. Manual of quality analyses for soybean products in the feed industry. 2ed. France: USSEC, 2015. Available in: https://ussec.org/wpcontent/uploads/2015/10/Manual-of-Quality-

Analyses.pdf. Accessed in: 20 Jun. 2019.

YUAN, S.; CHEN, D.; ZHANG, K. et al. Effects of oxidative stress on growth performance, nutrient digestibilities and activities of antioxidative enzymes of weanling pigs. Asian-Australas. J. Anim. Sci., v.20, p.1600-1605, 2007.

ZADRAVEC, M.; MITAK, M.; JAKI TKALEC, V. et al. Microbiological categorization of feed and feedingstuffs by VDLUFA method. Vet. Stanica v.46, p.175-180, 2015. 